\title{
sciendo
}

\section{Opportunities for smart tourism: from human tourist guiding to virtual guiding in Bucharest}

\author{
Andreea MARIN-PANTELESCU \\ Bucharest University of Economic Studies, Bucharest, Romania \\ marin.andreea@com.ase.ro \\ Rodica Claudia POPESCU \\ Bucharest University of Economic Studies, Bucharest, Romania \\ rodica.popescu@rei.ase.ro \\ Mihaela ŞTEFAN (HINT) \\ 1 Decembrie 1918 University Alba Iulia, Alba Iulia, Romania \\ mihacont73@gmail.com
}

\begin{abstract}
Tourist destinations are based on new technologies to facilitate access of visitors to tourist attractions. The mobility of the tourists together with the access infrastructure to the tourist objectives is important in the coordination of the tourist flows. More and more self-organized tours will overshadow the travel agencies tours in the demand and preferences of tourists. As technology advances, the curiosity and need of tourists to experience something new develop. The stringent health security requirements in the 'new normal' social life during and post-pandemic times enforce radical changes of tourism, among which virtual tourism gains solid grounds. Virtual tours accessed via smartphones have largely replaced the classical guided tours, lately. Our research is aimed at finding new ways to help Bucharest turn into a smart tourism destination. Bucharest is a European capital that needs modernization, innovation, digitalization and greater exposure and promotion internationally. The paper discusses the new trends of smart tourist destinations, the ways and means by which a destination may become smart and attractive for tourists and proposes a virtual signposting for visiting tourist attractions in Bucharest. Through our research we contribute to the intelligent tourism development in Bucharest and we offer ideas for future smart tourism projects.
\end{abstract}

Keywords: Tourist mobility, virtual guiding, self-tourism, travel, smart tourism.

\section{Introduction}

Traffic liberalization is a fundamental right in the age of globalization, people around the world can easily exchange ideas and values and travel to any tourist destination on the globe.

Smart tourism is defined according to the technological capabilities of a particular destination, attraction or tourist itself. Many destinations are now being upgraded to include smart technologies in their operations, from payment methods to interactive activities.

The ultimate goal of smart tourism is to improve resource management efficiency, maximize competitiveness and improve sustainability through the use of technological innovations and practices.

Technology is at the heart of smart tourism. But the key is how this technology is used to make the travel agent (destination management organization, tourist attraction, hotel, restaurant, and so on) work more efficiently. 
The tourist destination becomes smart when smart accessibility options are used to tourist attractions, their interconnection in a circuit, by managing smart tourism projects and a real sustainability initiative (Smart Tourism and Smart Destinations, Sage).

In 2020, in Bucharest we have a number of 178 accommodation units (2\% of the total tourist units in Romania) with 21,809 accommodation places which represented $6 \%$ of the total accommodation places in Romania. Regarding the arrivals of tourists accommodated in the structure of tourists' reception in Bucharest, in 2019 we had 2,038,858 of which 890,790 Romanians and 1,148,068 foreigners. The total number of tourist arrivals in Bucharest represents $15 \%$ of the total number of tourist arrivals in Romania. Out of the total arrivals of foreign tourists in Romania, $43 \%$ of them represent arrivals of foreign tourists in Bucharest (INS, 2021). We observe a significant percentage.

The capital city has international visibility being the first tourist destination in Romania in the preferences of foreign tourists for both business and leisure tourism.

The main purpose of our study is focused in examining a new concept of self-tourism mobility in Bucharest. The project consists in connecting the main touristic places in Bucharest through a virtual orange line painted on the sidewalks giving tourists the opportunity to self-visit our city without the need of a human tourist guide. The travel experience is born from tourist mobility (either physical or virtual) and the tourist's itinerary in Bucharest will be proposed in our paper. In the end some conclusions are to be made and some thoughts on future research directions will be taken into consideration.

\section{Literature review}

The quality of life in a particular region nowadays depend heavily on innovation, sustainability, accessibility and technology. All these four elements combined can create a smart city. Combining technology with leisure, and business with mobility provides the incentives to a relaxed travel experience (Buhalis \& Amaranggana, 2014).

A smart city is a concept of urban development that integrates technologies and systems to efficiently and securely manage a city's resources, in order to improve the quality of life of citizens, community development and environmental protection (Álvarez-García et al., 2016). These include, but are not limited to: local IT departments, transportation systems, hospitals, water distribution networks, waste management, schools, libraries, public agencies, and other community services such as tourism (Manika, 2020).

The concept of smart city includes six major areas (Radu, 2020; Vegacomp, 2020): smart environment (waste management, renewable energy, monitoring of environmental parameters), smart mobility (flexibility, efficiency, safety, technology with low environmental impact and integration, regardless variety of means of transport, charging stations, traffic management, electric public transport), smart government (online taxes and fees), smart people (education and health of the city), smart living (public Wi-Fi and public transport, tourism and promotion) .

Tourism has become internet dependent and tourists are in search of learning and having fun and also sharing all this with their family and friends. Posting and taking photos is not enough, because tourists need to be seen and heard in an instant. All this is only possible using the internet connection. A firm and innovative partnership between the public and private sector is always needed in the tourism industry.

The travel experience is important for tourists and in search of learning something new all the time. From the interaction between locals and tourists can arise new experiences. Using augmented reality, the past is new and the history is alive in tourism. Old castles, palaces, and 
museums are rebranded using the new technology (Racz \& Zilizi, 2019). A good Wi-Fi connection without disruptions for tourism activities is essential and always welcome in a tourism destination. The infrastructure is making the difference in the tourism attractiveness for all kinds of visitors (Hannam, 2019).

Yang \& Zhang (2014) argue the importance of smart behaviour in smart cities through education. Education is the key to human development, open-minded people will be able to manage the cities (Pelau et al., 2021).

According to Rzevski et al. (2020) and to Tcholtchev \& Schieferdecker (2021) a tourism destination needs a high-tech system including Open Data, Internet of Things, Big Data.

As tourists we need the internet and augmented reality to resurrect the past, to participate in a principal ball or to imagine a ruthless battle. With the help of smart applications, you may achieve everything that you want (Romão, 2020).

The expansion of the tourist market is through the free Wi-Fi helping on one hand the local community and on the other hand the tourists (Lamsfus et al., 2014). The geolocating is crucial for the tourism industry as it enhances the safety of the tourist's groups (Choi et al., 2019). Providing weather information for tourists, open hospitals and local restaurants are essential in tourism businesses.

In order to become a smart tourist city, six basic requirements are considered according to figure no. 1 Ways for becoming a smart tourism destination, namely: tourist information centres, free Wi-Fi, mobile apps with geolocation, virtual or augmented reality solutions, safety and health services, mobility.

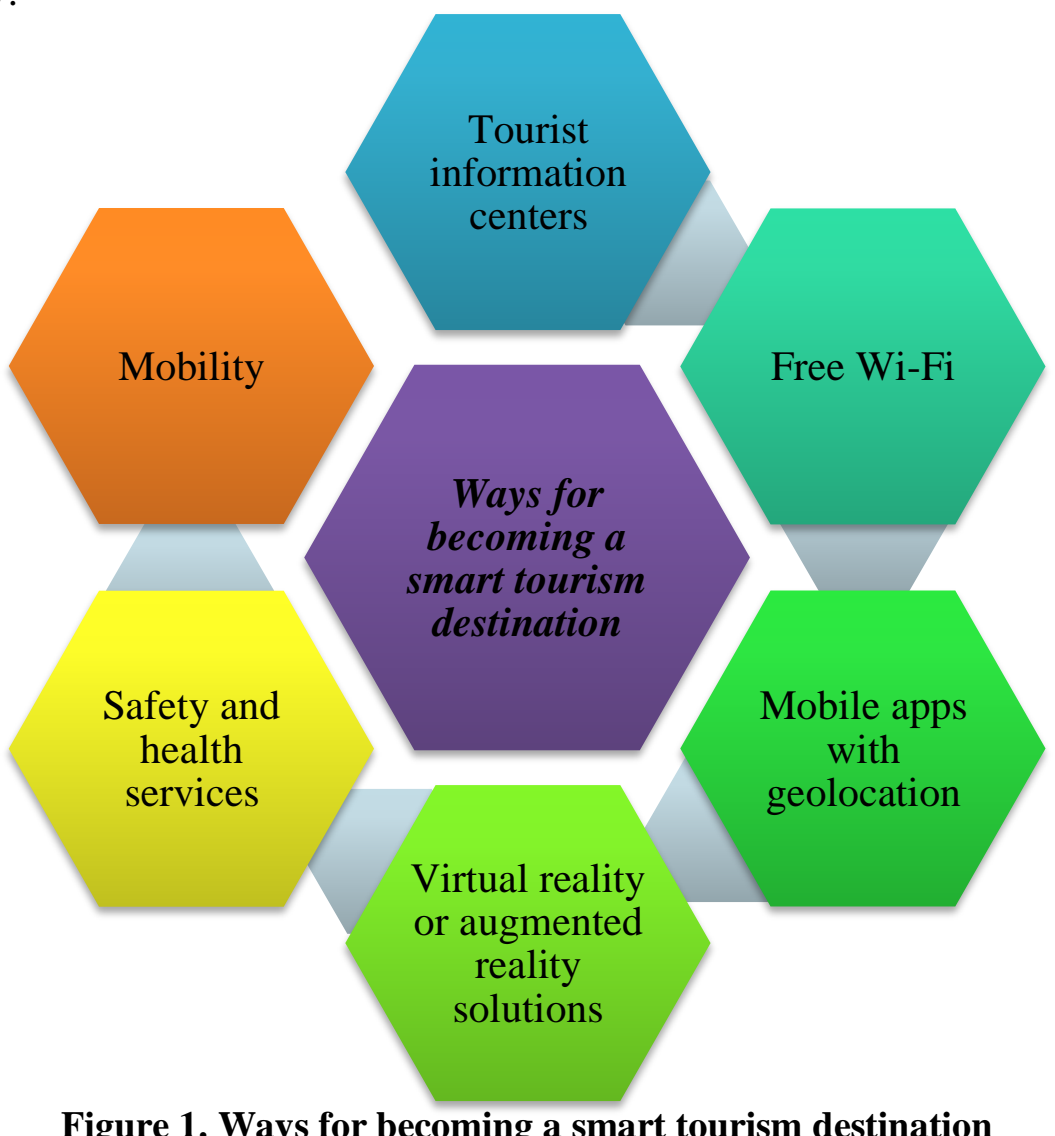

Source: Created by the authors based on the information provided by https://www.tourism-review.com/. 
Information about traffic, local infrastructure, hotels and restaurants, entertainment places all in one single smartphone application represents the future of tourism, spinning from classic to virtual.

The European Capital of Smart Tourism runs projects in major cities around the world, which follow four main directions of action (SmartTourismCapital.eu, 2019): sustainability through care for the environment, creativity through innovation, accessibility through gadgets and mobile apps, interculturality through interaction with locals. The developed projects are intense, modern and present models to follow for the other European cities.

It is worth mentioning Gothenburg and Malaga, cities that managed to be on the first place in the smartest cities in Europe.

European Capital of Smart Tourism was won by Gothenburg at the sustainability section, in 2020, and by Malaga at the accessibility section, in 2019.

Gothenburg is a city concerned with sustainability. Future generations must enjoy all the cultural and historical attractions of the city. Preserving the city is a priority for the Gothenburg authorities. Education focuses on conservation issues.

Min Stad is a $3 D$ city model that can be used by stakeholders to be better informed about the city's attractions. Renewable and recycled sources are a common thing in Gothenburg as $90 \%$ of all buildings are heated using district heating. In Gothenburg, 92\% of the city's hotels and 100\% of the conference rooms are ecologically certified. In conclusion, Gothenburg has been ranked the most sustainable destination in the world by the Global Destination Sustainability Index (Gothenburg.com/en/calculate-your-co2-emissions, 2020; cleverciti.com, 2020).

On the other hand, Malaga has improved in terms of digitalization. A cultural city of reference on the map of Europe, Malaga has created a network of tourist attractions positioned on smartphone applications. In this way, tourists are their own guides and satisfy their historical and cultural curiosities. In Malaga, we have the possibility to use bicycles as a means of transport, tourists being receptive and happy to this way of moving around the city.

The reduction of water consumption was achieved through a high-performance irrigation system for parks and gardens in the city. Noise and pollution reduction have been referenced strategies for tourist destination managers. Malaga had a management team that did all the cleaning procedures for nature conservation, and they succeeded (Malagaturismo, 2020).

Digitization is an primordial part of the tourist experience in Malaga as well, and the city has a high-profile digital sector. This includes the Digital Polo at Tabacalera and the Andalusian Technology Park (PTA). In 15 years, the city has become the "City of Museums", with over 30 museums to visit (cleverciti.com, 2020).

Romania has 24 smart cities and the most important are: Alba Iulia, Oradea, Cluj-Napoca, Bucharest, Piatra Neamt, Brasov, Arad, Sibiu, Constanta, Iasi (Vegacomp, 2020). Cluj and AlbaIulia are the cities that have the highest number of projects in the country, implemented in order to technologize the community, over 100 projects. Among the projects implemented by Alba-Iulia there are intelligent lighting, air quality monitoring, smart parking, traffic monitoring system and other intelligent solutions, monitoring water consumption and network losses. In Cluj-Napoca, the local authorities accessed funds to turn the city into a smart one. The local public administration introduced for the first time in Romania the first virtual civil servant, named Antonia, who will be available to citizens 24 hours a day. Among other projects in Cluj Napoca are worth mentioning free Wi-Fi in public places, adaptive traffic - purchase of electric buses, trams and trolleybuses. Arad is also making progress to become a smart city. The local authorities accessed funds to install 
30 hotspot assets, bike-sharing, electronic catalogues for the 22 existing educational units in the city, smart parking lots, etc.

Regarding Bucharest, on the website of the Romanian Association for Smart City and Mobility (https://romaniansmartcity.ro/, 2021) there are listed four "smart city" modules: Smart Energy, Bike Sharing, Electric Buses, IT\&C Terminals self-service type, and the representatives of this association say that steps are being taken to further develop the capital city in this regard. The project "Development of a smart city Smart City Bucharest" worth 500 thousand lei (100,000 euro) was won by tender company Delloite. The Smart City Bucharest project is a publicprivate partnership between the Delloite company and the Capital City Hall for the period 2018-2025. The benefits of the project will address: traffic management, tourism with intelligent tourist services, and intelligent transport-mobility (Mediafax, 2018).

\section{Methodology}

The research methodology is based on empirical data analysis and descriptive analysis, investigation of internet sources, secondary data analysis, document study and theoretical documentation.

In terms of tourist information centres: first of all, we have the Tourist Information and Promotion Centre at Northern Railway Station, the Tourist Information and Promotion Centre in Nicolae Bălcescu Passage at the University metro station, Bucharest Visitor Center (Boulevard Carol I 27), the Regional Resource Centre in Tourism (Boulevard George Coşbuc No. 42-44), all located in places with high accessibility.

Further information can be sourced from the 'Romania Travel Guide' website is one of the main projects of the "Romania Online" Non-Profit Association. The basic idea began to take shape in 2012 at the initiative of a group of students who were fully dedicated to the developers and implementation of this ambitious project.

Additionally, the Bucharest City Tour is operational from June 1-October 31 each year, and we present it as an example the year 2019. Thus, the Bucharest City Tour tourist line runs with four double-decker buses. Bucharest City Tour is a tourist line that runs on the Hop-On/Hop-Off system, meaning you can get on or off at any station on the route. Buses run daily, during the season, at intervals of 20-25 minutes, on the route between Unirii Square and Press Square. The buses have a capacity of 77 seats each, of which 50 on the platform. These buses also provide a place for people with disabilities. Bucharest City Tour route map is the following: 1. Unirii Square; 2. University Square; 3. Roman Square; 4. Victoriei Square; 5. Charles de Gaulle Square; 6. King Mihai I Park; 7. Village Museum (Muzeul Satului); 8. Press Square; and return 9. Village Museum; 10. Arch of Triumph; 11. Victoriei Square; 12. Revolution Square; 13. CEC; 14. Parliament House. The general operating schedule of the tourist line is 10:00 a.m.-09:46 p.m. The last bus that leaves the race from Piata Unirii to Piata Presei is at 09:25 p.m. and withdraws at station 7, Muzeul Satului, when the tour ends. The schedule with the first hour of arrival/departure from each station is available on: http://bucharestcitytour.stbsa.ro/images/map/program_statii_bucharest_citytour.pdf. Ticket price for Bucharest City Tour is affordable ranging from 25 lei (5 euro) for adults to 10 lei ( 2 euro) for children between aged 7-14 years; under the age of 7 the ride is free. Purchase of travel cards is done directly from the bus with CASH / POS (card) methods of payment. Travel cards are valid for 24 hours from the first validation, during the operating hours of the tourist line. Tourists thus benefit from the advantage of flexibility in choosing the program and objectives of interest. AUDIO GUIDE: Romanian/ English / French / Italian. The audio guide can also be downloaded on your own smartphone from the Izi.Travel application: https://izi.travel/en/b3f7-bucharest-city- 
tour/en. Clarifications for using the application: http://bucharestcitytour.stbsa.ro/images/brosuri/ 2019/afis_izy2019.jpg.

Duration of the route is about 50 minutes and, on request, a map of the route and headphones are provided.

The tourists will discover the local culture and notice the environments during a holiday sunny leisure walk. Tourists having the possibility to organize themselves will be able to personalize their city tour.

In finding the most beautiful, brand new and unique tourist attractions in a holiday destination, visitors can access the search engines Google, Bing, Bing Maps and Bing Locations. Through settings based on criteria and options, a virtual world is opened for the precise location of all tourist attractions with an error of one step. The more the holiday destination is presented in the first 5 to 10 results for foreign tourists, the more attractive it is because the psychological component of consumer behaviour appears, so predominantly people intuitively choose from the first proposals if the tourist services offered correspond to their desires.

The Internet has daily accessed tourism platforms, of which the most accessed for tourist information are in a descending order: Booking.com, Tripadvisor.com, Expedia.com, Hotels.com, Foursquare.com, Turistinfo.ro, Trivago.ro, Momondo .ro, Travel.ro.

The tourism blogs most appreciated by tourists' fans are very important to make an idea about tourism destination that they want to enjoy. According to Zelist in collaboration with Biz magazine in 2019, within Digital Report, a synthesis of the best travel blogs in Romania was made. Blogs were included with at least 5 posts within a year and with at least three articles published in the last three months of the analysed period January 1, 2018-December 31, 2018 (Lipa-lipa, 2019). The ranking included a wide range of blogs: aventurescu.ro, bloguldecalatorii.ro, calatoruldigital.ro, extravita.ro, imperatortravel.ro, lipa-lipa.ro, lumeamare.ro, mihaijurca.ro, povestidecalatorie.ro, prinlume.com, ralucalatoreste.ro, razvanpascu.ro, simonamocanu.ro, tedoo.ro, tickettonomadland.com, travelwithasmile.net, travelzoom.ro, turismmarket.com, valizacucalatorii.ro, visatorprinlume.ro, xplorio.ro.

\section{Results and discussions}

By practicing smart tourism, tourist attractions will offer visitors the experience they search for. The tourist experience can be personalized. Smart technology will make tourist attractions become more accessible, accomplishing consumer segmentation, providing a unique experience for each traveller.

In the situation of avoiding the transmission of Covid-19 disease, the intelligent signalling technology called crowd tracking will allow us to see the free areas and crowded areas, how tourists interact and who is in their vicinity.

Geographic labelling offers us new opportunities to promote tourist attractions. Tourist destinations can use smart technology to attract tourists directly to their vicinity. Tourist destinations can also promote their site in the off-season and can highlight the periods when they are more crowded or not crowded, being able to access new market segments quickly and easily.

Local transport is vitally important for a tourism destination. The locals can build smart tourism by using interactive routes in order to overcome congestion.

More public transport resources can be allocated to create tourism offers for tourists and city dwellers.

The travel experience is born from tourist mobility (either physical or virtual) and some of the main tourists itineraries in Bucharest are Herăstrău Park - Press House - Village Museum - 
Arch of Triumph- Grigore Antipa Museum - Geology Museum - Romanian Peasant Museum Victoria Palace - George Enescu Museum - Creţulescu Church - Romanian Athenaeum - Palace of Telephones - National Museum of Art of Romania - University Library - Parliament Palace - CEC Palace - National History Museum - Stavropoleos Church - Romanian Patriarchate - Manuc's Inn - Old Court - Museum Bucharest - Coltea Hospital - University of Bucharest - Museum of Literature - Academy of Economic Studies - Astronomical Observatory - Victoria Palace - Charles de Gaulle Statue, - Monument to the Heroes of the Air.

Taking into consideration the entire documentation made, we suggest the following: the unification in a single circuit of the tourist attractions marked with a virtual orange line (like in the figure no.2): A Bucharest Northern Railway Station, B Romanian Athenaeum, C National Museum of Art, D Parliament Palace, E Old Town Bucharest, $F$ Arch of Triumph, G „Dimitrie Gusti" National Village Museum. On their own, tourists following the line marked in orange and having in their smart mobile phone all the indications about tourist attractions, will be able to discover Bucharest through their own eyes. Also, being called Little Paris, the Past View smart glass glasses are intended to be used in Bucharest and the buildings of another time to take shape in the eyes of tourists eager to know and to experience new historical, cultural, and emotional sensations.

We chose six representative and diverse tourist attractions. They can be personalized and represent a symbol for which Bucharest is recognized internationally.

Smart internet systems can detect crowds of people, can direct traffic, and redirect tourist flows. The technology of the future offers us the opportunity to be responsible tourists who value the health of others. The resources are used sustainably and the regeneration of the tourist areas with the help of technology will be a real benefit for the local communities. Also, the reviews are important and worthy of consideration in tourism and easy and fast to manage using the technology of the future, namely the internet.

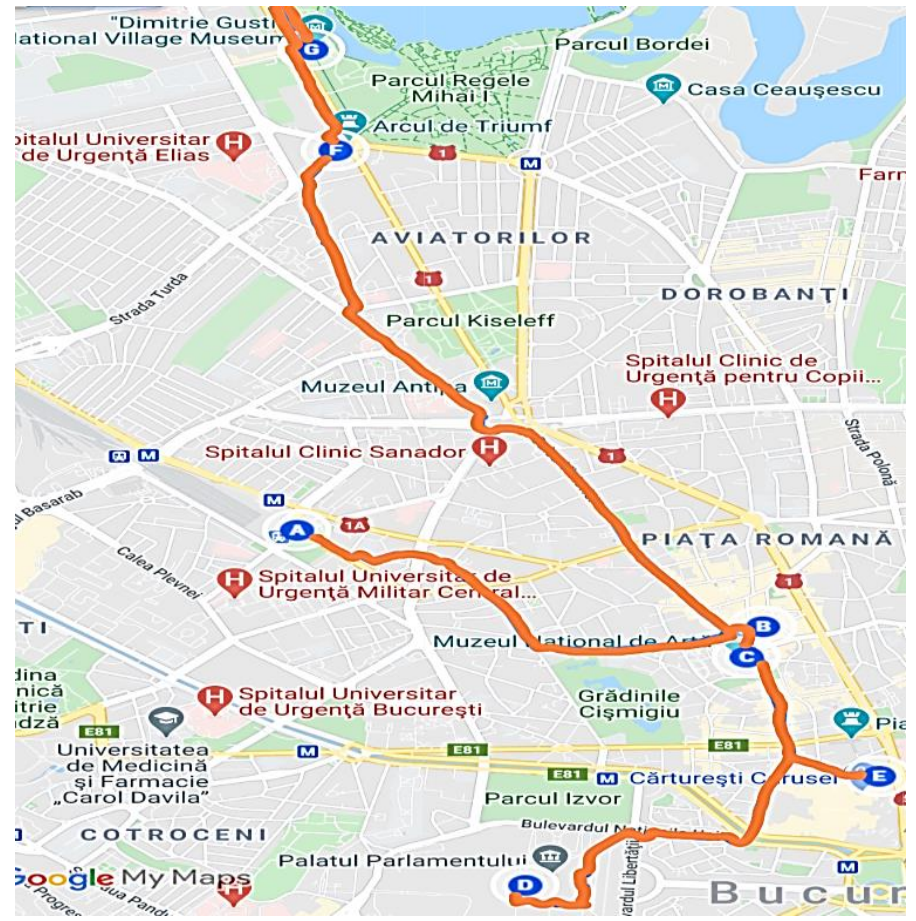

Figure 2. Bucharest virtual orange line for tourism attractions

Source: Created by the authors. 
Our proposals (as shown in figure no.3 Bucharest smart city with benefits for tourism) are functional Crowd management applications in Bucharest.

Crowd management systems are no longer a fad. They have become a necessity. Using GPS, we can estimate the number of visitors to the tourist destination. If there are too many tourists, we can try to reorient the flows to other tourist attractions in Bucharest.

We need an indoor navigation system in Bucharest that involves guiding and accompanying the visitor from the airport to the city centre. Moreover, we can tell him when he has the scheduled flight. In this way, the tourist's stress is reduced, while the time to be spent at tourism attractions is longer.

Museums are happy to offer virtual tours and robots can do it at a high level. A highperformance robot that offers virtual tours is at the Antipa Museum in Bucharest, well ranked in the preferences of tourists.

Tours offered by robots in the Old Centre of Bucharest are attractive and enchanting for young people.

Airbnb and Uber are two smart and necessary applications for the tourism industry and mostly for foreign tourists.

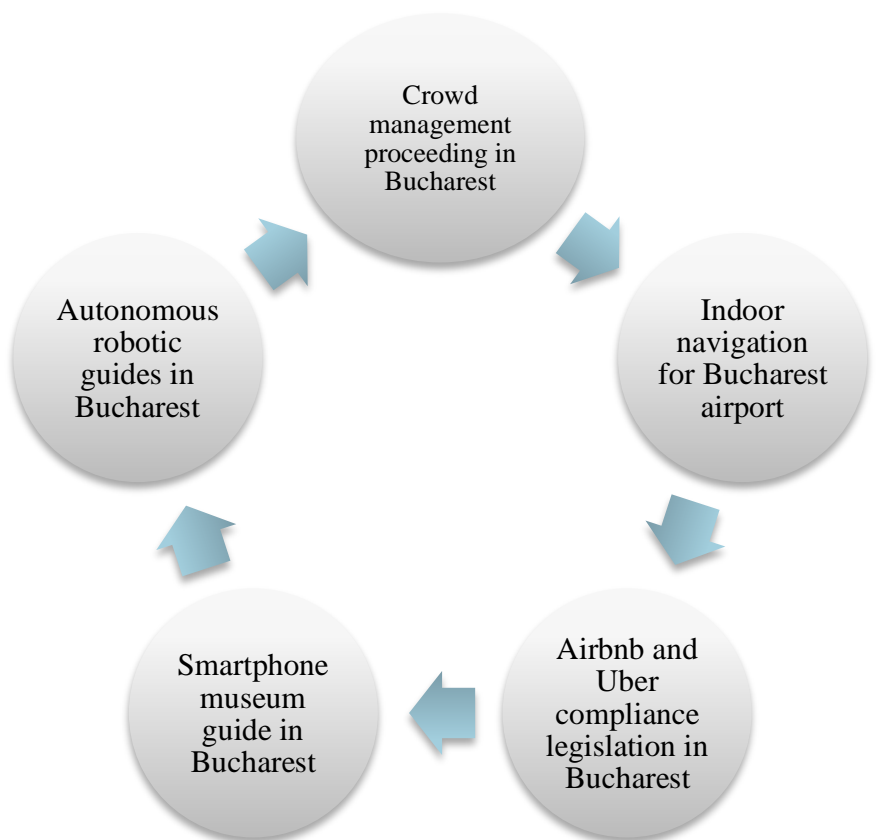

Figure 3. Bucharest smart city with benefits for tourism

Source: Created by the authors based on the information provided by deloitte-nl-ps-smart-cities-report.pdf.

\section{Conclusion}

The Covid-19 pandemic made us change our life priorities. Now tourists are concerned about health and safety in the tourist destination. The managers of the tourist destinations are looking for digital solutions to facilitate the development of the tourist actions. More than ever we need to go on vacation and feel safe. Technologies can give us this psychological comfort.

Smart cities emerge as the result of many smart solutions, from smart mobility to smart tourism and leisure. 
Tourism is sensitive and dependent on people and technology. A smart city will lead to sustainable projects with positive effects for the development of tourism in Bucharest. There are good initiatives from local authorities and prestigious companies to make Bucharest a smart tourist city.

Gadgets, smartphones, virtual reality, and robot tourist guides are common notions in developed tourist areas. For Bucharest we are at the beginning of the road but with special forces and initiatives like: intelligent waste collection projects, electric cars, electric charging pumps, virtual tours, greening, harmony between locals and tourists. With all these projects we can have hopes of making Bucharest a smart tourist destination.

Through our proposal, a virtual orange line, we support a modern, diversified, customized, easy, and challenging route toward smart tourism.

\section{References}

Álvarez-García, J., del Río-Rama, M. de la C., Vázquez-Huerta, G., \& Rueda-Armengot, C. (2016). Smart City and Tourism: An Analysis of Development of Caceres (Spain) as a Smart City, Sustainable Smart Cities, 199-218, doi:10.1007/978-3-319-40895-8,_15.

Asociația Română pentru Smart City (coord.) 2021. online: https://romaniansmartcity.ro/, accessed: 18.02.2021.

Bucharest City Tour (coord.). (2019). Bucharest City Tour, online:https://www.facebook.com/ bucharestcitytour/, accessed: 18.02.2021.

Bucharest City Tour (coord.). (2019). Bucharest City Tour,, online:http://bucharestcitytour. stbsa.ro/images/map/program_statii_bucharest_citytour.pdf, accessed: 18.02.2021.

Buhalis, D., \& Amaranggana, A. (2014). Smart Tourism Destinations Enhancing Tourism Experience Through Personalisation of Services, Information and Communication Technologies in Tourism 2015, 377-389, Available at: http://dx.doi.org/10.1007/978-3319-14343-9_28.

Choi, I. Y., Ryu, Y. U., \& Kim, J. K. (2019). A recommender system based on personal constraints for smart tourism city, Asia Pacific Journal of Tourism Research, 1-14, doi:10.1080/10941665.2019.1592765.

Cleverciti Resources Library (coord.) (2021). online: https://www.cleverciti.com/, accessed: 19.02.2021.

Gothenburg Official Visitor Guide (2021). online: https://www.goteborg.com/en/calculate-yourco2-emissions/, accessed: 19.02.2021.

Hannam, K. (2019). Smart cities, smart tourism, and smart mobilities. Handbook of Globalisation and Tourism, 260-268. doi:10.4337/9781786431295.00033.

INS (2021). National Statistical Institute, Available at: https://insse.ro/cms/ro/content/turism-77

Izi.Travel (coord.) (2019). Download the free izi.travel app, online: https://izi.travel/en/b3f7bucharest-city-tour/en, accessed: 19.02.2021.

Lamsfus, C. et al. (2014). Smart Tourism Destinations: An Extended Conception of Smart Cities Focusing on Human Mobility, Information and Communication Technologies in Tourism 2015, 363-375, Available at: http://dx.doi.org/10.1007/978-3-319-14343-9_27.

Lipa-lipa.ro (coord.) (2019). Cele mai bune bloguri de calatorii din Romania, online: https://ipalipa.ro/2019/03/cele-mai-bune-bloguri-de-calatorii-din-romania/, accessed: 18.02.2021.

Malaga received the Smart Tourism Award in Accessibility, granted by the European Commission (coord.) (2018). Online: http://www.malagaturismo.com/en/news/detail/malaga-received- 
the-smart-tourism-award-in-accessibility-granted-by-the-european-commission/783, accessed: 18.02.2021.

Manika, S. (2020). Mechanisms for Innovative-Driven Solutions in European Smart Cities, Smart Cities, 3(2), 527-540, doi:10.3390/smartcities302002.

National Statistics Institure (coord.) (2021). online: http://statistici.insse.ro:8077/tempo-online/ \#/pages/tables/insse-table, accessed: 19.02.2021.

Oprea, N. (2018). https://www.mediafax.ro/social/gabriela-firea-a-semnat-cu-deloitte-contractulpentru-strategia-de-smart-city-a-capitalei-17368941, accessed: 18.02.2021.

Pelau, C., Ene, I. and Pop, M.I. (2021). The Impact of Artificial Intelligence on Consumers' Identity and Human Skills, Amfiteatru Economic, 23(56), 33-45.

Racz, A., \&Zilizi, G. (2019). Virtual Reality Aided Tourism, 2019 Smart City Symposium Prague (SCSP). doi:10.1109/scsp.2019.8805727.

Radu, L.-D. (2020). Disruptive Technologies in Smart Cities: A Survey on Current Trends and Challenges, Smart Cities, 3(3), 1022-1038, doi:10.3390/smartcities3030051.

Romão, J. (2020). Tourism, smart specialisation, growth, and resilience, Annals of Tourism Research, 84, 102995, doi:10.1016/j.annals.2020.102995.

Rzevski, G., Kozhevnikov, S., \& Svitek, M. (2020). Smart City as an Urban Ecosystem, Smart City Symposium Prague (SCSP). doi:10.1109/scsp49987.2020.9133849.

Smart Cities How rapid advances in technology are reshaping our economy and society (coord.). (2021). online, https://www2.deloitte.com/tr/en/pages/public-sector/articles/smart-cities .html, accessed: 18.02.2021.

Smart Tourism and Smart Destinations (n.d.). The SAGE International Encyclopedia of Travel and Tourism, doi:10.4135/9781483368924.n413.

SmartTourismCapital.eu (coord.) (2019). Oare orașul tău va fi prima capitală europeană a turismului inteligent?, online https://smarttourismcapital.eu/wp-content/uploads/2018/08/ Factsheet_RO.pdf, accessed: 19.02.2021.

Tcholtchev, N., \&Schieferdecker, I. (2021). Sustainable and Reliable Information and Communication Technology for Resilient Smart Cities, Smart Cities, 4(1), 156-176. doi:10.3390/smartcities4010009.

Vegacomp Consulting (coord.) (2020). Analiză - Radiografia Smart City în România Ediția a IVa, Iunie 2020, online, https://vegacomp.ro/wpr/wp-content/uploads/2020/07/update_1_ raport-radiografie-smart-city-romania-2020.07.08.pdf, accessed: 18.02.2021.

Vizitez Romania (2021). online:https://romaniatravel.guide/ro/, accessed: 18.02.2021.

Weekes, S. (2019). Gothenburg and Málaga win smart tourism award, online: https://www. smartcitiesworld.net/news/news/gothenburg-and-malaga-win-smart-tourism-award-4676, accessed: 19.02.2021.

Yang, Z., \& Zhang, X. (2014). Smart education in smart city, assisted by WebGIS. Remote Sensing and Smart City. doi:10.2495/rssc140251. 